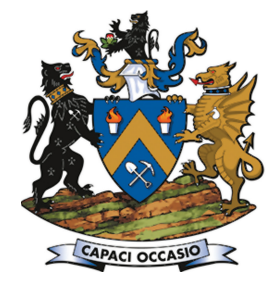

\title{
Presidential Address: Post-mining use of rehabilitated land - an opportunity for the South African mining industry for sustainable development
}

\author{
M.I. Mthenjane ${ }^{1}$
}

Affiliation:

1Exxaro Resources Ltd,

South Africa.

Correspondence to:

M.I. Mthenjane

Email:

mzila.mthenjane@exxaro.com

Dates:

Received: 5 Sep. 2019

Published: September 2019

How to cite:

Mthenjane, M.I

Post mining use of rehabilitated

land - an opportunity for the

South African mining industry for sustainable development.

The Southern African Insitute of Mining and Metallurgy

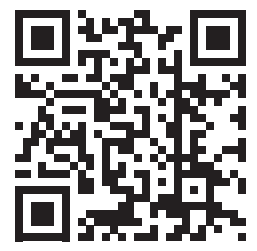

Presidential Address Video

\section{Background}

The paper discusses post-mining land use however, the essence of the topic is the emotional motivation behind the decisions related to mining investment and development. Therefore this is not a typical SAIMM technical paper about the science and techniques of post-mining land use. There are already numerous papers written and conferences held on this aspect of post-mine land use; the science is well understood, but the evidence of the practical application of the (environmental, social, and economic) science is sparse. At a recent conference held in November 2017 on the theme of 'Science, Business, Society Dialogue - linking science, society, business and policy for the sustainable use of abandoned mines in the SADC region', it was demonstrated through the delivery of several papers on the possible viable options of post-mine land use. The conference was structured in nine sessions, covering the following relevant topics:

> Sessions 1 and 2: Nature and magnitude of the problem: raising awareness

> Sessions 3 and 4: International experiences in remediation: case studies

> Sessions 5, 6 and, 7: Technological solutions: converting liabilities into assets

> Session 8: Implementing solutions: social and legal aspects

> Session 9: Wrap up, lessons learned: conference resolution.

Summaries of the key outcomes of the sessions are available for reference.

The aim of this paper, accompanied by the video speech, is to provide a visualization of the possibilities of post-mine land use. Mining contributes approximately $7 \%$ to South Africa's GDP - this is the lowest it has ever been and is attributable to both a diversifying economy and to poor mining and investment policy which has resulted in reduced investment in the sector. The objective of the paper is to highlight the opportunities, for succeeding and diversifying economic activity following mining and mineral extraction which can continue to sustain the livelihoods and wellbeing of communities and societies beyond mining.

During mining, very few alternative and local economies develop. Dependence on mining and its value chain prevails until mining ceases. This idea is conveyed in Figures $1 \mathrm{a}$ and $\mathrm{b}$.

Several mining regions in South Africa (and elsewhere in the world) are experiencing post-mining poverty as mines close due to unfavourable market conditions and resources are depleted. What follows is typical mine closure plans which have had no consideration for the economic wellbeing of the communities that have established themselves around the mining activity. This paper and the associated video aim to demonstrate the increasing recognition and acknowledgement by mining companies that economic wellbeing of communities and the country does not have to cease with the end

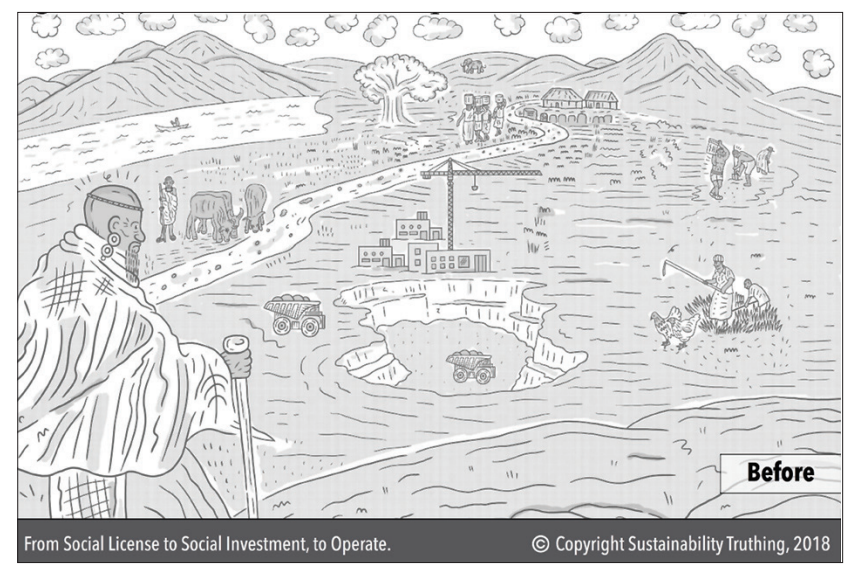

Figure 1a-Socio-economic impact during mining 


\section{Post-mining use of rehabilitated land - an opportunity for the South African mining industry}

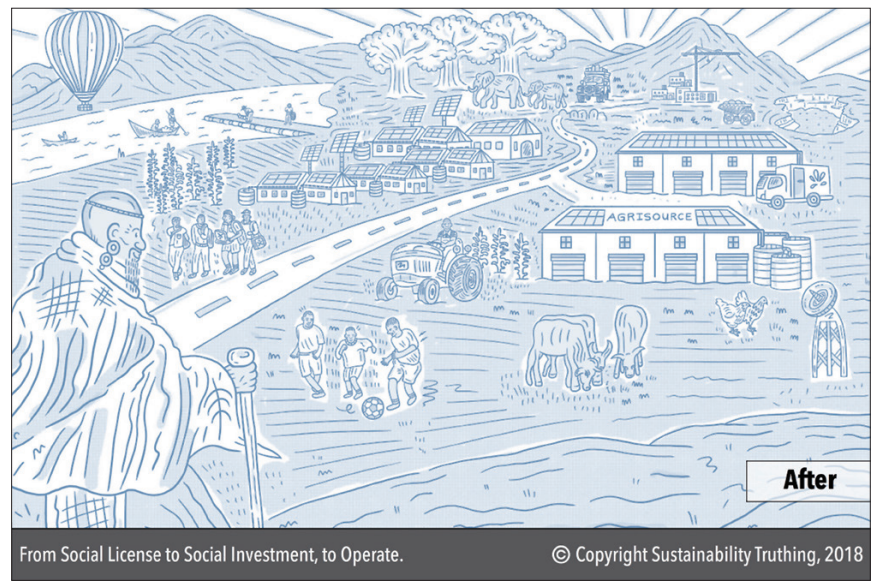

Figure $1 \mathrm{~b}-$ Socio-economic possibilities beyond mining

of the life of mine. Economic succession planning is a concept where post-mine land use explores the possibilities of positive economic development and continuing social impact long after a mine has closed.

The paper should be read together with the video provided in the attached QR code which shows some of the possibilities of post-mine land use, with specific reference to opencast mining. There's no doubt that underground mining also provides for different post-mine land use, other than agriculture. The vacated underground spaces lend themselves to several uses, subject to safety, health, and cost considerations, especially with deep level mining in gold and platinum mining.

\section{Introduction}

Over the two decades of my career the landscape of the global mining industry has changed fundamentally. In South Africa it has changed irrevocably. As industry professionals and leaders, it is incumbent on us not only to salvage what remains of our sector, but grow it from what is now a low base relative to the size and international profile of the industry on the country's transformation to democracy in 1994. As an industry, and by implication as an Institute, we have to think very carefully and very creatively as to where and how we take the sector from here to the future and more importantly, how the sector takes people from here to the future, given its predefined duration.

I start the discussion with mineral succession planning, but I'll end with something very different from this starting point. As a matter of fact, that is the key message of this address, that where we have started with the development of a mine for mineral exploitation is not, and should not be, to end mining exploitation activity with no consideration of a better future beyond mining; and the question becomes, if not a vastly minedout landscape, what will we end up with? The possibilities are found in what I believe are three essential leadership attributes that we need today in our society and mining in particular: firstly, visioning a better future and progress for humanity, secondly, a dose of courage to challenge orthodoxy and explore new opportunities, and lastly the will to selflessly act for the benefit of others, rather than for ourselves.

When I was growing up as a 'younger' mining engineer in the goldfields of the Witwatersrand, my senior managers used to say that 'mining is a people business'. I've always wondered what that means? Which people are we referring to?
Is it the many workers who strive and work in these mines?

> Is it about those who are outside the mine and having expectations of some benefit from the mine?

Is it not obvious that mining is a people business? Both those who are working within and those outside of mining looking towards it. In fact, what business is not about people?

\section{Digging for the heart of mining}

If mining was a people business, how should people be treated? Are we exemplary as an industry today on the fair and equitable treatment of people, considering the social and environmental impact from our decisions and actions related to mining investment and decision-making? Are we demonstrating sincere consideration and humaneness to the environmental impact, which is visible and tangible, and acknowledging our ignorance/ nonchalant attitude towards the social fractures that it causes, which are subtle and veiled by the short-term economics - are we 'digging for the heart of mining' to provide the compassionate input required for mining investment and development decisionmaking, in addition to financial and technical viability? This is a call for leadership, the traits described above and application of systems engineering and thinking which is currently lacking in mine design and planning to make a lasting impact of mining on the wellbeing of people.

While some concessions for the conduct of mining towards the environment can be offered (and only some), because of the unavoidable disturbance to landscape, flora and fauna, the negative impact on people's livelihoods in pursuit of profit is unforgivable. Mining has a long history in South Africa and a rather unpleasant one at that; but I don't intend to dig into the past (no pun intended at all). It's only in the recent 20 to 30 years that we have begun to understand the balance required in mineral exploitation such that we show care to people and really make mining a people business, placing human wellbeing at the centre of its business - this endeavour still remains off-centre, but we are beginning to see signals of hope for the future of communities arising from mining.

To achieve the balance suggested from the Figure $2 \mathrm{a}$, some have proposed more stringent legislation, higher penalties for transgressing mines, and confiscating the mining permits. But what good would this do for the majority of those communities who depend on mining for a livelihood? More and more, the call 


\section{Post-mining use of rehabilitated land - an opportunity for the South African mining industry}

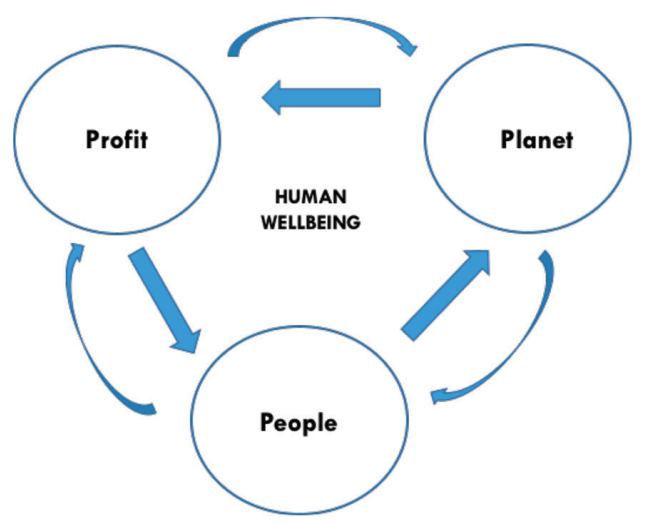

Figure 2a-Triple bottom line - balance of social (people), economic (profit), and environment (planet) for human wellbeing (sustainability)

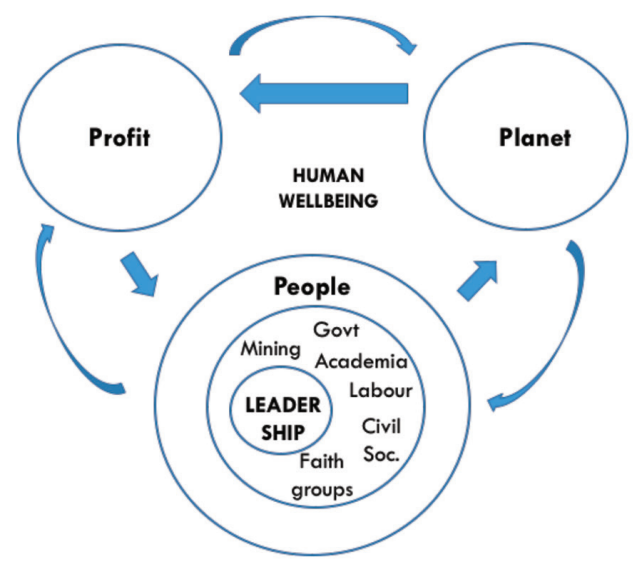

Figure $\mathbf{2 b}$-Leadership is/leaders are, from amongst us...collaboration of leaders amongst social partners can result in high-impact and sustainable initiatives

for leadership is growing louder as a possible solution - the industry needs leadership in order to live up to its promise of being a people business. But where does one find this leadership? Why is it hard to find? Is it not born yet or is it still in the making?

The mining industry continues to evolve, and leadership is emerging from within the people who are directly and indirectly affected by mining - it is leadership with a heart and the mindset to understand that a mine is part of a social system profit must be pursued with due consideration for the wellbeing of people by balancing people's needs and what is sourced from nature with the profits from the mine, which should benefit the community and greater society. Figure $2 \mathrm{~b}$ is an reinterpretation of the well-known triple bottom line model for sustainability to illustrate this perspective on leadership.

A practical illustration - in Limpopo, a Collaborative Regional Development Platform is being established amongst social partners that include the participation and leadership of the Provincial government, through the office of the Premier, two South African-based and global mining companies, a (global) civil society organization and domestic $R \& D$ institution to work together towards better outcomes from mining which will stimulate regional economic development and diversify the economy of the Province. It's an exciting venture to look forward to.
It's not an easy task to act out of the norm and comfort of what we have become used to for the past and more than 100 years of mining in South Africa; however, given the current socio-economic challenges, it is a task that is necessary and achievable when the vision is clear.

The scar on nature (and society) that results from mining, especially opencast mining, is unavoidable. The question is - do we have a mining leadership that sees beyond the short-term benefits from this scarring of the Earth to the possibilities of new economies when mining has been completed? Do we have to leave closed mining operations in this condition? Do any of us have an image of a post-mining activity and economic succession long after the mining economic returns have filled our bellies? The possibilities are endless. To name a few:

- Agriculture and mining are complementary activities, in spite of conflicts of land use which may arise at times. However, as mining activities decline and mines approach closure, the rehabilitated land that becomes available can be used for a varied range of large-scale agricultural activities. given available technology and innovation tools. Further, the agricultural activities can succeed mining as part of the concurrent rehabilitation of the mined-out areas in surface mining operations.

- Energy - deep-level gold and platinum mines such as found in South Africa are suitable for underground pumped hydroelectric storage (UPHES). The UPHES concept involves pumping water while electricity is cheap into an upper reservoir, increasing the potential energy of the water. When the electricity is expensive (during daytime on weekdays) the water flows back to the lower reservoir generating electricity through turbines which is sold to Eskom. A profit to run the system is derived from the price difference between electricity used for pumping and the significantly more expensive electricity generated. However, $20 \%$ more energy is needed to run the whole system than what can be generated. This system could therefore not be solely relied upon to provide all energy needed, but is designed to complement other forms of energy. The idea is to use part of the existing underground mine void as an upper reservoir on one or more levels, with a pressure pipe connecting to a lower reservoir, and pumps and turbines (separately positioned) that either pump or generate energy. There is also the potential to develop geothermal energy generating opportunities.

- Tourist attractions and multi-purpose facilities - there are several examples from around the world where prior mining locations have been repurposed for leisure activities, viz, Eden Project ('from pit to paradise') in Cornwall, UK was previously a china clay pit and is now a tourist attraction with a diversity of activities ....; the Butchart gardens was once the location of a limestone quarry and is now one of the most beautiful gardens (the Sunken Garden) in Canada and is now designated a National Historic Site of Canada attracting over 1 million visitors a year.

\section{The SAIMM and sustainable development from mining}

Over the last eight years the Institute has pivoted from its purely technical focus and has been encouraging papers and discussions on matters relating to environment, social licence, and policy, and in my view, these discussions have been complementary to 


\section{Post-mining use of rehabilitated land - an opportunity for the South African mining industry}

our primary mandate of technical discourse. One of the areas that has attracted increasing attention is that of the post-mining landscape, which includes not only physical rehabilitation of the damage created by mining, but attention to the social and environmental impacts of mine development and closure on mining-affected communities. From a policy perspective, current statutes and regulations in the MPRDA, NEMA, and the Water Act are limited to physical rehabilitation and none of these statutes deal in any way with the social consequences of mine closure. Social and Labour Plans and Corporate Social Investment cease on mine closure while mine closure provisioning is restricted to physical rehabilitation.

These burning issues need to be addressed and redressed and this imperative will constitute the primary focus of my Presidency. In May this year my predecessor, Alistair McFarlane suggested that the Institute's Technical Programme Committee, (the TPC) introduce a bespoke Post-Mining Landscape workstream. The recommendation was endorsed at the May 2019 Council meeting and Professor Michael Solomon, a Member of Council and Chairman of the Mineral Economic Division of the Institute was asked to provide a proposal for the imperative for approval of Council. This decision will fall within my term and I will pick up the reigns of the initiative. I will commit to raising the profile of the imperative and ensure that it has significant traction by the time I pass the baton to the next President.

The objective of this workstream is to build on work done over a number of years by Prof Solomon. The Mineral Economics Division was established under the Presidency of Gys Landman and in 2010 undertook a substantial piece of research into the call for the nationalisation of South African mines. The research report, which recognized and highlighted the enormous stress affecting mining communities in the platinum belt, was released at the Mining Indaba in Cape Town in 2012. Since then Professor Solomon's work has focused on the theme of Economic Succession Planning for South African Mines which is directed towards ensuring a post-mining economic future for miningaffected communities.

The imperative considers the concurrent diversification of mining land, infrastructure, and water to provide for parallel and successive economies to mining that are not dependent on the mining activity itself. The parallel economy constitutes a transitional economy while mining is still active and develops into a substitutive economy on closure of the mine. The construct provides a value proposition for the mining company by transforming mining land, effectively a liability in mine closure terms, into a balance sheet asset with a considerably reduced rehabilitation liability. More importantly, it provides for a postmining economy for the mining-affected and dependent mining communities.

There are three specific projects currently underway that are actively working on the development of post-mining economies, and I would like to table these as possible case studies of the principles and tenets of ensuring economy beyond mining. The first is Sibanye-Stillwater which has announced the closure of Cooke Shafts 1, 2, 3 and 4 and has made 16000 hectares of land available for redevelopment for the economic benefit of the mines, retrenched workers and dependent communities. The second project is a platinum mine on the Western Limb where an innovative, integrated post-mining economic project is underway. The mine has a 30 to 40-year life of mine and has sufficient time to diversify its land and infrastructure for agriculture and tourism and ensure that these alternative economies have traction and are sustainable by mine closure. The third case study is my own company, Exxaro, which is developing a very large opencast coal mining project in an environmentally sensitive area. However, this is only one example where the company can demonstrate and develop this concept of economic succession planning.

By creatively developing economic succession planning principles into the actual design of the mine, the sustainable economic viability of the project's affected communities is ensured by using mining as the catalyst for other forms of economic activity. Highlighting actual projects we will demonstrate the feasibility of the approach and demystify its design principles. It will also focus on what works and what does not, and in so doing provide a pragmatic proof of concept for our members to follow, learn, emulate the successes, and avoid the failures.

In conclusion, during my term as President of the Institute, I will be actively promoting programmes that develop a better understanding of the current contribution that mining makes to society and the broader economy with a view to the proactive planning of post-mining economies. This will require an assessment of the present impact that mining makes to the country's monetary, social and political economy and the contribution it can make in catalysing broad-reaching sustainable economic development, not only for affected communities but for the country as a whole. At the centre of this imperative will be the proactive contribution that the mining industry can make to achieving the objectives of all 17 of the United Nations Sustainable Development Goals (SDGs). For example, the concept of resource- exhausted mine land reclamation advances SDG 15 , which focuses on life on land. Ecological systems theory can provide a good starting point for understanding transitions to sustainability.

I aim to commit the Institute to an ongoing programme to build awareness of the need to provide for post-mining economies and critical role that our members can play in the active participation as an imperative. I will also strive to create strategic relationships and partnerships between the SAIMM and other organizations currently supporting the Economic Succession Planning imperative.

In closing I would like to commit my Presidency to furthering the cause of minerals-driven sustainable development and the advancement of social benefit from mining activity. These noble intentions can be achieved only with the cooperation of and collaboration with the leadership of the mining industry and the conscientization of our membership, (a large component of the current and future leadership of the industry) on the criticality of social stability in mining communities and perceptions of equitable benefit sharing on the part of mining-affected people. I invite you, our membership and constituency, during and beyond my Presidency, to help achieve this bold vision to benefit our and future generations.

\section{References}

Sustainability Truthing. presentation to Exxaro Resources, 2 August 2019.

Linking Science, Society, Business and Policy for the Sustainable Use of Abandoned Mines in the SADC Region. Science Business Society Dialogue conference, Indaba Hotel, 28-30 November 2017.

Professor Michael Solomon. Economic Succession Planning, economy beyond mining - presentation to the SAIMM Council, 29 March 2019.

https://www.edenproject.com

https://www.butchartgardens.com

The Future of Mining in South Africa: Sunset or Sunrise. Mapungubwe Institute for Strategic Reflection (MISTRA). A Mistra Publication. 